132

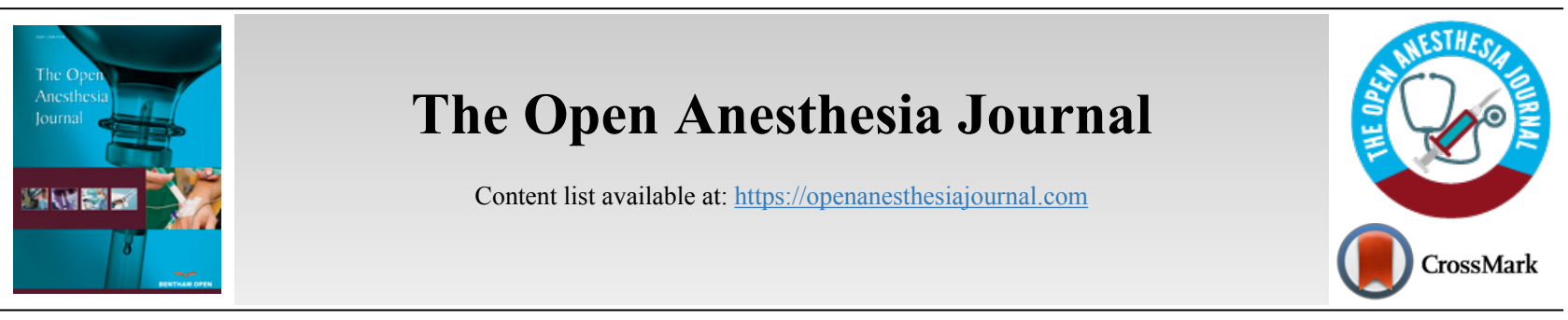

RESEARCH ARTICLE

\title{
Ketamine Infusion in Post-Surgical Pain Management after Head and Neck Surgery: A Retrospective Observational Study
}

\author{
Vincenzo Pota ${ }^{1, *}$, Maria B. Passavanti ${ }^{1}$, Caterina Aurilio ${ }^{1}$, Manlio Barbarisi ${ }^{2}$, Luca G. Giaccari ${ }^{1}$, Umberto Colella ${ }^{3}$, \\ Marco Fiore ${ }^{1}$, Giuseppe S. R. C. Mangoni di Santostefano ${ }^{1}$, Pasquale Sansone ${ }^{1}$ and Maria C. Pace ${ }^{1}$ \\ ${ }^{\prime}$ Department of Women, Child, General and Specialistic Surgery, University of Campania "L. Vanvitelli”, 80138 Napoli, Italy \\ ${ }^{2}$ Dipartimento Multidisciplinare di Specialità Medico-Chirurgiche e Odontoiatriche, Università degli Studi della Campania "Luigi Vanvitelli", \\ Campania, Naples, Italy \\ ${ }^{3}$ Department of Anesthesia, AORN Monaldi Hospital, Napoli, Italy
}

\begin{abstract}
:
Background:

Head and neck cancer affects approximately 382,000 new patients per year worldwide with a significant portion undergoing surgical treatment. During postoperative period key elements in the Intensive Care Unit (ICU) are airway management and pain control.

Objective:

We evaluated the average change of inpatient pain control using a Numerical Rating Score (NRS). We also evaluated the time of extubation after ICU admission recording the incidence of desaturation and the necessity of re-intubation. Secondary outcomes were the incidence of postoperative complications, included those narcotics-related, and the use of rescue analgesics.

Methods:

In this retrospective observational study, we analyzed data of registry before and after we have changed our postoperative analgesic protocol from remifentanil infusion to ketamine infusion.

Results:

Medical records of 20 patients were examined. 10 patients received $0.5 \mathrm{mg} / \mathrm{kg}$ ketamine bolus at the end of surgery, followed by a continuous infusion of $0.25 \mathrm{mg} / \mathrm{kg} / \mathrm{h}$. All patients presented a significant decrease in pain intensity from the $4^{\text {th }}$ to $48^{\text {th }}$ postoperative hour $(p<0.05)$, but statically not a significant difference in NRS score was recorded between the two groups. Time to extubation was shorter in ketamine group compared to the remifentanil group $(112.30 \mathrm{~min} \pm 16.78 v \mathrm{~s} .78 \mathrm{~min} \pm 14.17 ; p<0.05)$. Desaturation rate was $10 \%$ in the remifentanil group, while no case was recorded in the ketamine group.

\section{Conclusion:}

The level of analgesia provided by ketamine and remifentanil was comparable. Ketamine was superior in ventilatory management of the patient with more rapid extubation and with no case of desaturation.
\end{abstract}

Keywords: Head and neck cancer, Intensive care unit, Ketamine, Remifentanil, Pain control, Airway management, Ventilatory management.

\section{Article History}

Received: July 29, 2019

Revised: September 25, 2019

Accepted: October 14, 2019

\section{INTRODUCTION}

Head and neck cancer affects approximately 382,000 new patients per year worldwide [1], with a significant portion of these patients undergoing surgical treatment. Due to the complexity and aesthetic importance of head and neck anatomical

\footnotetext{
* Address correspondence to this author at the Department of Women, Child, General and Specialistic Surgery, University of Campania "L. Vanvitelli", Piazza Miraglia 2, 80138 Napoli, Italy; Tel: 00393664485084 ;

E-mail: Vincenzo.pota@unicampania.it
}

structures, reconstruction with free tissue transfer is often required to achieve optimal postoperative function and appearance [2].

According to Enhanced Recovery After Surgery (ERAS) protocol for people undergoing surgery for head and neck cancer, during the postoperative phase in Intensive Care Unit (ICU) key elements are the airway management, including for those patients for whom a tracheostomy has been placed, and the pain control [3]. Standard of care for pain management and 
sedation in patients ventilated in ICU is a continuous infusion of opioid (i.e. remifentanil or morphine), associated with hypnotic sedative agents (i.e. midazolam or propofol).

Ketamine is a Non-competitive N-Methyl-D-Aspartate (NMDA) receptor blocker. It stimulates the cardiovascular system increases heart rate, blood pressure and cardiac output, mediated principally through the sympathetic nervous system [4]. It has minimal effects on central respiratory drive and produces airway relaxation by acting on various receptors and inflammatory cascades and bronchial smooth muscles [5]. It increases salivation and muscle tone [4]. Ketamine has cataleptic, amnestic, profound analgesic, and dose dependent anaesthetic actions [4]. The cataleptic state is an akinetic state with the loss of orthostatic reflexes, but without impairment of consciousness [6].

For these characteristics, ketamine is commonly used for acute pain management in calculation was performed; pain, particularly in patients who are opioid-tolerant. In these contexts, subanaesthetic doses are generally used [7]. Ketamine is also used in the critical care unit, providing combined sedation and analgesia [8].

Traditionally, remifentanil is used in ICU to ensure effective analgesia and adequate sedation [9, 10].

In our ICU, from November 2018, we changed the analgesic protocol from the opioid regimen to non-opioid one, based on ketamine infusion.

In this retrospective observational study, we analyzed data of registry before and after we have changed our postoperative analgesic protocol for a patient admitted in ICU after head and neck surgery.

The primary endpoint of this study was to determine the average change of inpatient pain control using NRS between experimental and control groups. The other primary endpoint was to evaluate the time of extubation after ICU admission. We evaluated the incidence of desaturation $\left(\mathrm{SpO}_{2}<90 \%\right)$ analyzed by continuous respiratory monitoring and the necessity of reintubation.

The incidence of postoperative complications included those narcotics-related and use of rescue analgesics were the secondary outcomes.

\section{MATERIALS AND METHODS}

\subsection{Patients}

This monocentric retrospective study was conducted collecting and examining the medical records of 20 patients admitted to the ICU of "Luigi Vanvitelli" University Hospital (Piazza Luigi Miraglia 2 - Naples, Italy) in the period between May 1, 2018 and May 31, 2019.

The Institutional Review Board approved this investigation and all procedures were in accordance with the Declaration of Helsinki. Patients scheduled for head and neck cancer surgery and admitted in ICU were enrolled after signed written informed consent.

We performed a retrospective review of patients who underwent head and neck cancer surgeries with free flap reconstruction receiving ketamine and acetaminophen in ICU from December 1, 2018 to May 31, 2019. We compared these patients with a group of patients with similar characteristics receiving remifentanil and acetaminophen from May 1, 2018 to November 30, 2018. No prior sample size was performed; however, all eligible patients were considered.

Ketamine/acetaminophen group (K/A group) received 0.5 $\mathrm{mg} / \mathrm{kg}$ ketamine bolus at the end of surgery followed by a continuous infusion of $0.25 \mathrm{mg} / \mathrm{kg} / \mathrm{h}$ of ketamine and acetaminophen $1000 \mathrm{mg}$ every $8 \mathrm{~h}$. During the six months before, we administered remifentanil at $0.01-0.03 \mathrm{mg} / \mathrm{kg} / \mathrm{h}$ infusion rate and acetaminophen $1000 \mathrm{mg}$ every $8 \mathrm{~h}(\mathrm{R} / \mathrm{A}$ group).

The inclusion criteria were as follows:

1. Patients undergoing head and neck cancer ablation with concomitant free flap reconstruction surgery.

2. Patients naïve to ketamine.

3. Adult patients $>18$ years of age and able to consent.

The exclusion criteria were as follows:

1. Patients who are already taking scheduled ketamine.

2. Poorly controlled cardiovascular disease.

3. Patients with known renal compromise, such that creatinine clearance is $<30 \mathrm{~mL} / \mathrm{min} / 1.73 \mathrm{~m}^{2}$.

4. Patient with known hepatic insufficiency or cirrhosis.

5. Elevated intracranial pressure, elevated intraocular pressure.

6. Pregnant women.

7. Psychosis.

8. Patients allergic to ketamine.

The flow chart (Fig. 1) shows in detail the procedure of patients selection. 36 medical records were evaluated. Twelve patients did not meet the required inclusion criteria. From the remaining 24 patients, four had no interest in the study. Twenty patients were evaluated, and all of them were included for the present study.

The data supporting the findings of the article is available in the medical records archive of "Luigi Vanvitelli" University Hospital (Piazza Luigi Miraglia 2 - Naples, Italy).

We obtained demographics (age, sex, race), clinical (height, weight, Body Mass Index - BMI) and anaesthesiolocial (American Society of Anaesthesiologists - ASA - grade, duration of surgery) data.

At ICU admission all patients underwent standard blood exams including Arterial-Blood Gas (ABG) test, infectious investigations, Chest X-Ray (CXR) and Electrocardiogram (ECG). 


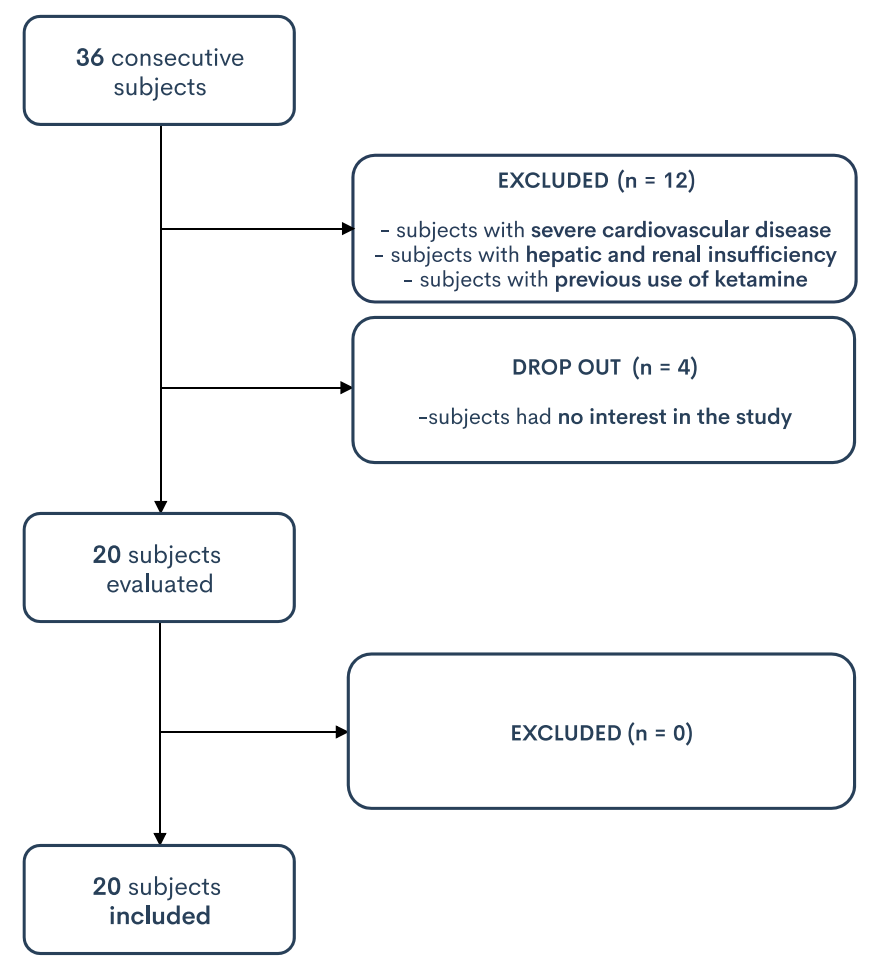

Fig. (1). Procedure of patients selection.

Arterial Pressure (AP), Mean Arterial Pressure (MAP), Heart Rate (HR), peripheral oxygen saturation $\left(\mathrm{SpO}_{2}\right)$ and Numerical Rating Scale (NRS) were recorded. Before surgery, all patients were educated on the use of NRS $(0=$ no pain, $10=$ worst possible pain).

Data were collected at ICU admission and 4, 8, 12, 16, 20, 24, and 48 hours postoperatively.

Hemodynamic adverse effects included new onset of tachycardia, bradycardia, hypertension and hypotension. Tachycardia and bradycardia were defined as a heart rate greater than 110 beats per minute (bpm) and less than 60 , respectively. Hypertension and hypotension were classified as a systolic blood pressure greater than $180 \mathrm{~mm} \mathrm{Hg}$ and less than $90 \mathrm{~mm} \mathrm{Hg}$, respectively.

Presence of delirium was determined using the Confusion Assessment Method for the ICU (CAM-ICU) at 24 hours after ICU admission.

\subsection{Statistical Analyses}

Data were analyzed using a standard computer program (Excel, 2016). Results were reported as mean \pm Standard Deviation (SD). Comparisons between group on mean pain value and extubation time were performed using Student t-test. The level of statistical significance was $p<0.05$.

This observational study is in accordance with the STROBE statement [11].

\section{RESULTS}

The medical records of twenty patients who underwent head and neck cancer surgeries with free flap reconstruction and then admitted to ICU were examined. Of these ten patients received ketamine and acetaminophen, the other 10 received remifentanil and acetaminophen. No patient was excluded for inadequate analgesia.

Patients enrolled for this study were similar according to age, sex, duration of surgery and ASA grade (Table 1).

Mean age was $57.6 \pm 8.9$ years in $\mathrm{K} / \mathrm{A}$ group and $60 \pm 6.0$ in $\mathrm{R} / \mathrm{A}$ group. $\mathrm{K} / \mathrm{A}$ group included 5 female and 5 male patients, while in R/A group, there were 4 female and 6 male patients. In K/A group 3 patients were classified as ASA grade II and 7 patients as ASA grade III, while in R/A group 4 patients as ASA grade II and 6 patients as ASA grade III. Duration of surgery was $679.2 \mathrm{~min} \pm 64$ in $\mathrm{K} / \mathrm{A}$ group and $677.5 \mathrm{~min} \pm 72.5 \mathrm{in} \mathrm{R} / \mathrm{A}$ group.

Patients were classified according to NRS score as none pain 0 , mild pain 1-3, moderate pain 3-6 and severe pain 6-10.

All patients presented a significant decrease in pain intensity from the $4^{\text {th }}$ to $48^{\text {th }}$ postoperative hour $(p<0.05)$, but statically not a significant difference in NRS score was recorded between the two groups (Table 2 and Figs. 2 - 5).

Time to extubation was shorter in K/A group compared to $\mathrm{R} / \mathrm{A}$ group $(112.30 \mathrm{~min} \pm 16.78 v s .78 \mathrm{~min} \pm 14.17 ; p<0.05)$ (Fig. 6). The desaturation rate was $10 \%$ in the R/A group, while no case was recorded in the K/A group. This difference is statistically not significant. In no case, reintubation was necessary.

Patients in both groups well-tolerated ketamine and remifentanil. There were no adverse hemodynamic events, but 
$\mathrm{K} / \mathrm{A}$ group presented a mean arterial pressure higher that $\mathrm{R} / \mathrm{A}$ group. Rescue analgesics were not administered.

\section{DISCUSSION}

Traditionally, free flap patients have been routinely monitored in ICU, even after uncomplicated surgery. An immediate postoperative period of deep sedation and artificial ventilation in ICU is often required. This is associated with prolonged time to weaning from mechanical ventilation and an increase in the frequency of respiratory insufficiency and pneumonia, as compared with allowing patients to breathe spontaneously with light sedation [12].

Table 1. Patient data.

\begin{tabular}{|c|c|c|c|}
\hline GROUPS & REMIFENTANYL + PARACETAMOL & KETAMINE + PARACETAMOL & - \\
\hline AGE & 57,6 (DS 8.9) & 60 (DS 6.0) & $p 0.8$ \\
\hline GENDER & - & - & - \\
\hline MALE & $60.0 \%$ & $50.0 \%$ & - \\
\hline FEMALE & $40.0 \%$ & $50.0 \%$ & - \\
\hline ASA & - & - & - \\
\hline II & $40.0 \%$ & $30.0 \%$ & - \\
\hline III & $60.0 \%$ & $70.0 \%$ & - \\
\hline DURATION OF SURGERY & 677,5 (DS 72,5) & $679,2(\mathrm{DS} 64,1)$ & $p .5$ \\
\hline
\end{tabular}

Table 2. Mean pain value.

\begin{tabular}{|c|c|c|c|c|c|c|c|c|}
\hline \multicolumn{9}{|c|}{ PAIN INCIDENCE } \\
\hline- & $\begin{array}{c}\text { REMIFENTANYL } \\
+ \\
\text { PARACETAMOL }\end{array}$ & $\begin{array}{c}\text { KETAMINA + } \\
\text { PARACETAMOL }\end{array}$ & $\begin{array}{c}\text { REMIFENTANYL } \\
+ \\
\text { PARACETAMOL }\end{array}$ & $\begin{array}{c}\text { KETAMINA + } \\
\text { PARACETAMOL }\end{array}$ & \begin{tabular}{|c}
$\begin{array}{c}\text { REMIFENTANYL } \\
+ \\
\text { PARACETAMOL }\end{array}$ \\
\end{tabular} & $\begin{array}{c}\text { KETAMINA + } \\
\text { PARACETAMOL }\end{array}$ & $\begin{array}{c}\text { REMIFENTANYL } \\
+ \\
\text { PARACETAMOL }\end{array}$ & $\begin{array}{c}\text { KETAMINA + } \\
\text { PARACETAMOL }\end{array}$ \\
\hline- & - & - & MILD (1-3) & - & MODERATE (4-6) & - & SEVERE (7-10) & - \\
\hline 0 & 7 & 8 & 2 & 1 & 1 & 1 & 0 & 0 \\
\hline $4 \mathrm{H}$ & 6 & 7 & 3 & 3 & 1 & 0 & 0 & 0 \\
\hline $8 \mathrm{H}$ & 6 & 6 & 3 & 3 & 1 & 1 & 0 & 0 \\
\hline $12 \mathrm{H}$ & 7 & 7 & 3 & 3 & 0 & 0 & 0 & 0 \\
\hline $16 \mathrm{H}$ & 8 & 8 & 2 & 2 & 0 & 0 & 0 & 0 \\
\hline $20 \mathrm{H}$ & 8 & 9 & 2 & 1 & 0 & 0 & 0 & 0 \\
\hline $24 \mathrm{H}$ & 8 & 7 & 2 & 3 & 0 & 0 & 0 & 0 \\
\hline $28 \mathrm{H}$ & 8 & 8 & 2 & 2 & 0 & 0 & 0 & 0 \\
\hline $32 \mathrm{H}$ & 8 & 8 & 2 & 2 & 0 & 0 & 0 & 0 \\
\hline $36 \mathrm{H}$ & 8 & 9 & 2 & 1 & 0 & 0 & 0 & 0 \\
\hline $40 \mathrm{H}$ & 8 & 9 & 2 & 1 & 0 & 0 & 0 & 0 \\
\hline $44 \mathrm{H}$ & 8 & 8 & 2 & 2 & 0 & 0 & 0 & 0 \\
\hline $48 \mathrm{H}$ & 8 & 8 & 2 & 2 & 0 & 0 & 0 & 0 \\
\hline MEAN & 7.538461538 & 7.846153846 & 2.230769231 & 2 & 0.230769231 & 0.153846154 & 0 & 0 \\
\hline SD & 0.745796901 & 0.863459397 & 0.421325044 & 0.784464541 & 0.421325044 & 0.360801212 & 0 & 0 \\
\hline
\end{tabular}

PAIN INCIDENCE TO

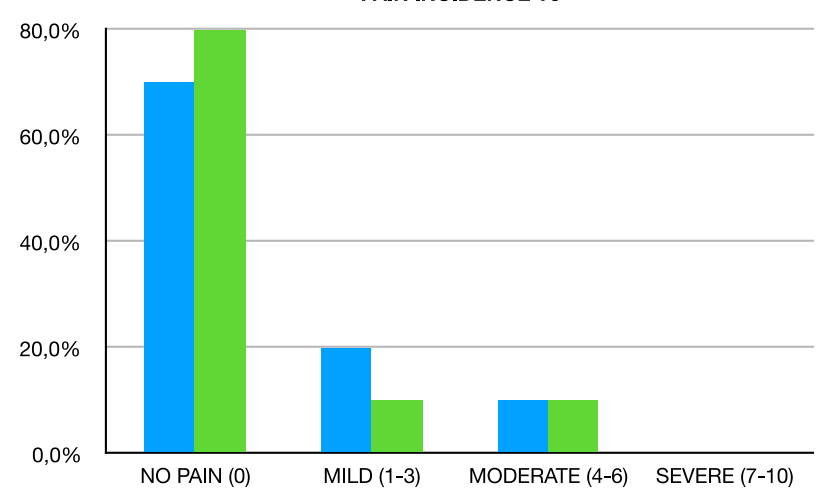

PAIN INCIDENCE 4H

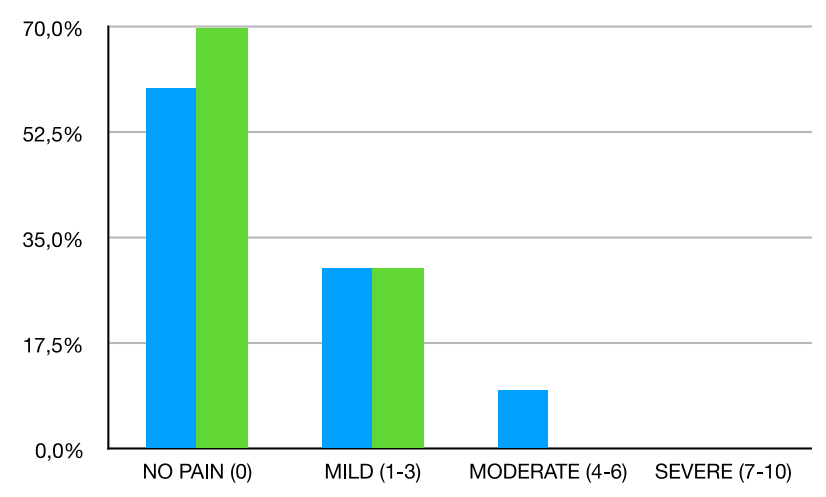

Fig. (2). Pain incidence time 0.

Fig. (3). Pain incidence $4 h$. 


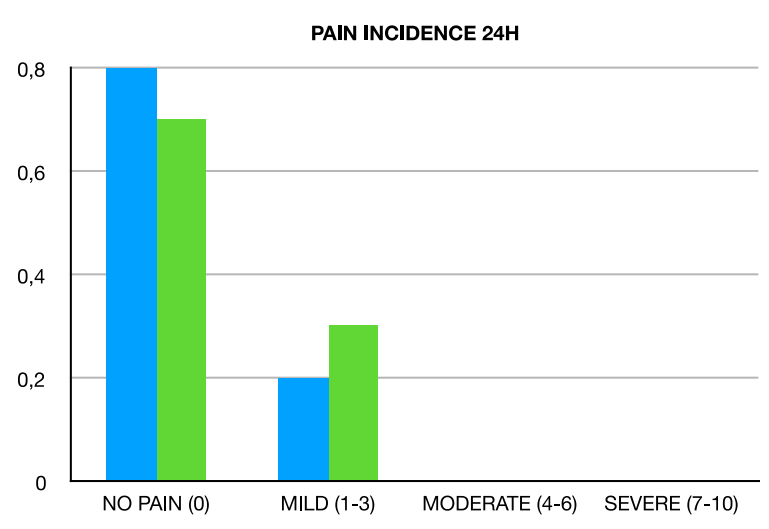

Fig. (4). Pain incidence $24 \mathrm{~h}$.

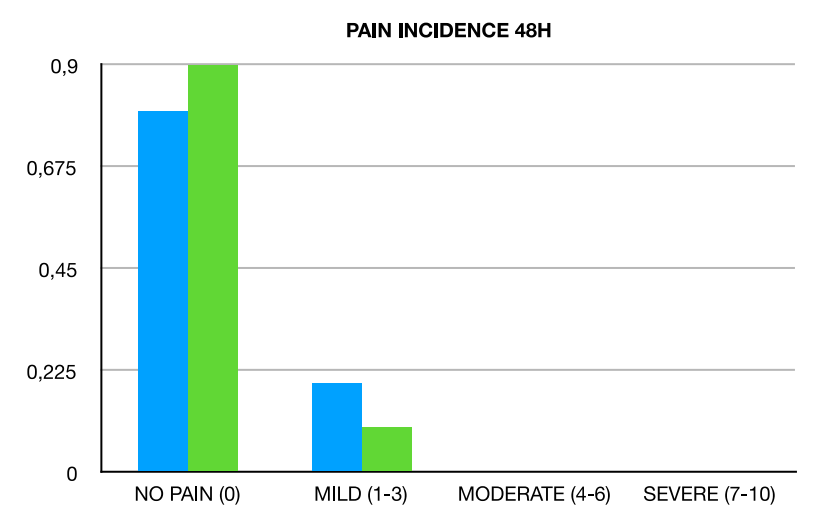

Fig. (5). Pain incidence $48 \mathrm{~h}$.

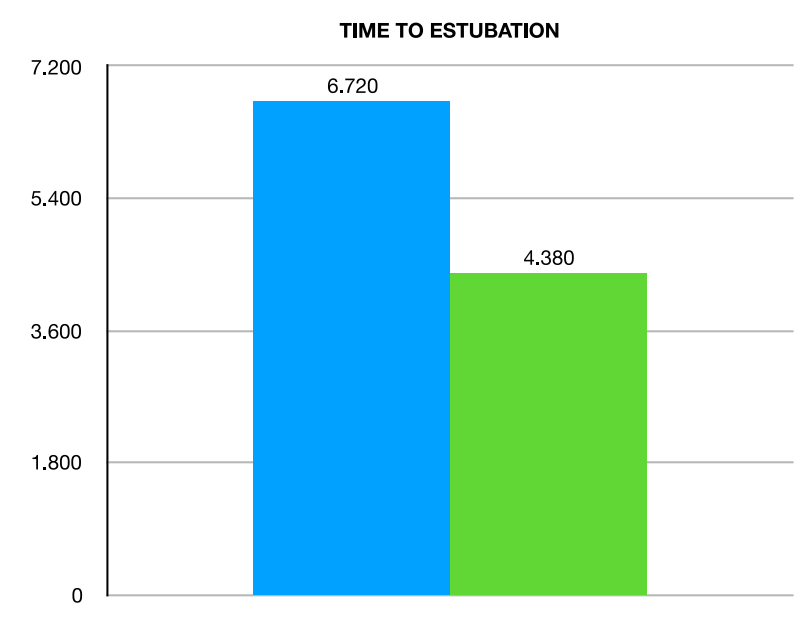

Fig. (6). Time to estubation.

In maxillofacial head and neck oncology, tracheostomy is often used to secure the airway especially from the risk of swelling and oedema in the postoperative period. Tracheostomy has several advantages; it ensures a more effective bronchial toilet and reduces the dead space in wean- ing from the mechanical ventilation. However, tracheos- tomy carries its own risks, such as haemorrhage, obstruction, displacement, stomal recurrence, and poor healing after radiotherapy [13]. There is growing evidence to suggest that many head and neck oncology cases can be managed without tracheostomy. In selected cases, postoperative ventilation with an endotracheal tube is an option to consider [14].

In free flap transfer, the goals of postoperative management are to maintain a full hyperdynamic circulation with increased cardiac output, peripheral vasodilation and normothermia to maximize flap perfusion. The haematocrit is maintained at $30-35 \%$ to improve oxygen transfer and red blood cell velocity within the microcirculation [13].

Pain control is another goal of postoperative management of patients undergoing head and neck surgery. Major head and neck cancer resections with free flap reconstruction are lengthy and complex procedures. These interventions have a major impact on postoperative patient comfort and can make pain management challenging [15]. Pharmacological control of pain often requires the use of narcotics, such as continuous infusion of morphine. These drugs can have many side effects that can make recovery more difficult including nausea, vomiting, dizziness, excessive sleepiness, itching, inability to urinate, confusion, inability to have a bowel movement, long time before you can start walking. These side effects can make the hospital longer. Recent evidence suggests a multimodal analgesia opioid-sparing, utilizing Nonsteroidal Anti-Inflammatory Drugs (NSAIDs), COX inhibitors, and parace- tamol [12].

The use of ketamine in head and neck surgery is controversial. Traditionally, it is recognized that it offers better sedation and analgesia with fewer respiratory effects when compared to other agents. In addition, it provides anxiolysis while maintaining cardiovascular stability [8]. In the last guidelines on the use of intravenous ketamine, patients undergoing procedures with expected mild levels of pain, such as head and neck surgery, have not been shown to benefit from perioperative ketamine [7]. However, ketamine is a 'usedependent' drug: it blocks NMDA channels only if they have already been opened by intense or repeated noxious stimuli [16]. It seems better to administer ketamine during the early postoperative days [17] by a continuous infusion of at least $0.25 \mathrm{mg} / \mathrm{kg} / \mathrm{h}$ [18].

In our study, ketamine has reduced time to extubation while guaranteeing good sedation. It has also proved to be safe, not causing adverse reactions. Desaturation did not occur, and there was no need to re-intubate patients. As known, early extubation reduces respiratory complications, such as Ventilator Associated Pneumonia (VAP), ICU-acquired weak- ness, and hospital length of stay [19 - 21].

Some limitations to our study should be considered. First, our study was conducted retrospectively. Second, the sample is limited to 20 patients.

\section{CONCLUSION}

According to previous studies [22 - 25], ketamine is a strong analgesic that can be used in subanaesthetic dose without significant neuropsychiatric effects. Ketamine reduces 
postoperative pain, and plays an important role in reducing opioid use, decreasing opioid side effects and increasing time for rescue analgesics. It offers good sedation with few respiratory effects, and it provides anxiolysis while maintaining cardiovascular stability.

In our study, the level of analgesia provided by ketamine and remifentanil infusion was comparable. Ketamine infusion showed advantages in ventilatory management of the patient with more rapid extubation and with no case of desaturation.

In the future, a prospective study could better investigate the efficacy of the ketamine infusion concerning a control group.

\section{LIST OF ABBREVIATIONS}

$\begin{array}{ll}\text { VAP } & =\text { Ventilator Associated Pneumonia } \\ \text { NSAIDs } & =\text { Nonsteroidal Anti-Inflammatory Drugs } \\ \text { SD } & =\text { Standard Deviation } \\ \text { bpm } & =\text { beats per minute } \\ \text { CAM-ICU } & =\text { Confusion Assessment Method for the ICU } \\ \text { ABG } & =\text { Arterial-Blood Gas } \\ \text { CXR } & =\text { Chest X-Ray } \\ \text { ECG } & =\text { Electrocardiogram } \\ \text { AP } & =\text { Arterial Pressure } \\ \text { MAP } & =\text { Mean Arterial Pressure } \\ \text { HR } & =\text { Heart Rate } \\ \text { NRS } & =\text { Numerical Rating Scale }\end{array}$

\section{ETHICS APPROVAL AND CONSENT TO PARTICIPATE}

The Institutional Review Board of Luigi Vanvitelli University Hospital (Piazza Luigi Miraglia 2 - Naples, Italy) approved this investigation.

\section{HUMAN AND ANIMAL RIGHTS}

No animals were used in this research. All human research procedures were followed in accordance with the ethical standards of the committee responsible for human experimentation (institutional and national), and with the Helsinki Declaration of 1975, as revised in 2013.

\section{CONSENT FOR PUBLICATION}

Patients scheduled for head and neck cancer surgery and admitted in ICU were enrolled after signed written informed consent.

\section{STANDARD OF REPORTING}

This observational study is in accordance with the STROBE statement.

\section{AVAILABILITY OF DATA AND MATERIALS}

Not applicable.

\section{FUNDING}

None.

\section{CONFLICT OF INTEREST}

The authors declare no conflict of interest, financial or otherwise.

\section{ACKNOWLEDGEMENTS}

Declared none.

\section{REFERENCES}

[1] Fitzmaurice C, Akinyemiju TF, Al Lami FH, et al. Global burden of disease cancer collaboration. Global, regional, and national cancer incidence, mortality, years of life lost, years lived with disability, and disability-adjusted life-years for 29 cancer groups, 1990 to 2016: A systematic analysis for the global burden of disease study. JAMA Oncol 2018; 4(11): 1553-68.

[http://dx.doi.org/10.1001/jamaoncol.2018.2706] [PMID: 29860482]

[2] Kinzinger MR, Bewley AF. Perioperative care of head and neck free flap patients. Curr Opin Otolaryngol Head Neck Surg 2017; 25(5): 405-10.

[http://dx.doi.org/10.1097/MOO.0000000000000384] [PMID: 28604404]

[3] Coyle MJ, Main B, Hughes C, et al. Enhanced Recovery After Surgery (ERAS) for head and neck oncology patients. Clin Otolaryngol 2016; 41(2): 118-26.

[http://dx.doi.org/10.1111/coa.12482] [PMID: 26083896]

[4] Kolawole IK. Ketamine hydrochloride: A useful but frequently misused drug. Niger J Surg Res 2001; 3: 118-25.

[http://dx.doi.org/10.4314/njsr.v3i3.12232]

[5] Goyal S, Agrawal A. Ketamine in status asthmaticus: A review. Indian J Crit Care Med 2013; 17(3): 154-61.

[http://dx.doi.org/10.4103/0972-5229.117048] [PMID: 24082612]

[6] Annetta MG, Iemma D, Garisto C, Tafani C, Proietti R. Ketamine: New indications for an old drug. Curr Drug Targets 2005; 6:7: 89-94.

[7] Schwenk ES, Viscusi ER, Buvanendran A, et al. Consensus guidelines on the use of intravenous ketamine infusions for acute pain management from the American Society of Regional Anesthesia and Pain Medicine, the American Academy of Pain Medicine, and the American Society of Anesthesiologists. Reg Anesth Pain Med 2018; 43(5): 456-66.

[http://dx.doi.org/10.1097/AAP.0000000000000806] [PMID: 29870457]

[8] Cromhout A. Ketamine: Its use in the emergency department. Emerg Med (Fremantle) 2003; 15(2): 155-9. [http://dx.doi.org/10.1046/j.1442-2026.2003.00433.x] [PMID; 12675625]

[9] Kuhlen R, Putensen C. Remifentanil for analgesia-based sedation in the intensive care unit. Crit Care 2004; 8(1): 13-4. [http://dx.doi.org/10.1186/cc2421] [PMID: 14975040]

[10] Battershill AJ, Keating GM. Remifentanil: A review of its analgesic and sedative use in the intensive care unit. Drugs 2006; 66(3): 365-85. [http://dx.doi.org/10.2165/00003495-200666030-00013] [PMID: 16526829]

[11] von Elm E, Altman DG, Egger M, Pocock SJ, Gøtzsche PC, Vandenbroucke JP. The strengthening the reporting of observational studies in epidemiology (STROBE) statement: Guidelines for reporting observational studies. Int J Surg 2014; 12(12): 1495-9. [http://dx.doi.org/10.1016/j.ijsu.2014.07.013] [PMID: 25046131]

[12] Dort JC, Farwell DG, Findlay M, et al. Optimal perioperative care in major head and neck cancer surgery with free flap reconstruction: A consensus review and recommendations from the enhanced recovery after surgery society. JAMA Otolaryngol Head Neck Surg 2017; 143(3): 292-303.

[http://dx.doi.org/10.1001/jamaoto.2016.2981] [PMID: 27737447]

[13] Anjum Ahmed-Nusrath. Anaesthesia for head and neck cancer surgery. BJA Educ 2017; 17(12): 383-9.

[http://dx.doi.org/10.1093/bjaed/mkx028]

[14] Coyle MJ, Tyrrell R, Godden A, et al. Replacing tracheostomy with overnight intubation to manage the airway in head and neck oncology patients: Towards an improved recovery. Br J Oral Maxillofac Surg 2013; 51(6): 493-6.

[http://dx.doi.org/10.1016/j.bjoms.2013.01.005] [PMID: 23929589]

[15] Hinther A, Nakoneshny SC, Chandarana SP, Wayne Matthews T, Dort JC. Efficacy of postoperative pain management in head and neck cancer patients. J Otolaryngol Head Neck Surg 2018; 47(1): 29. 
[http://dx.doi.org/10.1186/s40463-018-0274-y] [PMID: 29720267]

[16] Mion G. Ketamine stakes in 2018: Right doses, good choices. Eur J Anaesthesiol 2019; 36(1): 1-3.

[http://dx.doi.org/10.1097/EJA.0000000000000902] [PMID: 30520783]

[17] Zakine J, Samarcq D, Lorne E, et al. Postoperative ketamine administration decreases morphine consumption in major abdominal surgery: A prospective, randomized, double-blind, controlled study. Anesth Analg 2008; 106(6): 1856-61.

[http://dx.doi.org/10.1213/ane.0b013e3181732776] [PMID: 18499623]

[18] De Kock M, Lavand'homme P, Waterloos H. 'Balanced analgesia' in the perioperative period: Is there a place for ketamine? Pain 2001; 92(3): 373-80.

[http://dx.doi.org/10.1016/S0304-3959(01)00278-0] [PMID: 11376910]

[19] Blackwood B, Alderdice F, Burns K, Cardwell C, Lavery G, O'Halloran P. Use of weaning protocols for reducing duration of mechanical ventilation in critically ill adult patients: Cochrane systematic review and meta-analysis. BMJ 2011; 342: c7237. [http://dx.doi.org/10.1136/bmj.c7237] [PMID: 21233157]

[20] Coplin WM, Pierson DJ, Cooley KD, Newell DW, Rubenfeld GD. Implications of extubation delay in brain-injured patients meeting standard weaning criteria. Am J Respir Crit Care Med 2000; 161(5): 1530-6.

[http://dx.doi.org/10.1164/ajrccm.161.5.9905102] [PMID: 10806150]

[21] Vadivelu N, Schermer E, Kodumudi V, Belani K, Urman RD, Kaye AD. Role of ketamine for analgesia in adults and children. $J$ Anaesthesiol Clin Pharmacol 2016; 32(3): 298-306.

[http://dx.doi.org/10.4103/0970-9185.168149] [PMID: 27625475]

[22] Garber PM, Droege CA, Carter KE, Harger NJ, Mueller EW. Continuous infusion ketamine for adjunctive analgosedation in mechanically ventilated, critically ill patients. Pharmacotherapy 2019; 39(3): 288-96.

[http://dx.doi.org/10.1002/phar.2223] [PMID: 30746728]

[23] Umunna BP, Tekwani K, Barounis D, Kettaneh N, Kulstad E. Ketamine for continuous sedation of mechanically ventilated patients. J Emerg Trauma Shock 2015; 8(1): 11-5.

[http://dx.doi.org/10.4103/0974-2700.145414] [PMID: 25709246]

[24] Groetzinger LM, Rivosecchi RM, Bain W, et al. Ketamine infusion for adjunct sedation in mechanically ventilated adults. Pharmacotherapy 2018; 38(2): 181-8.

[http://dx.doi.org/10.1002/phar.2065] [PMID: 29193185]

[25] Wieruszewski PM, Leung JG, Nelson S. Ketamine use in the intensive care unit. AACN Adv Crit Care 2018; 29(2): 101-6.

[http://dx.doi.org/10.4037/aacnacc2018448] [PMID: 29875104]

\section{(C)2019 Pota et al.}

This is an open access article distributed under the terms of the Creative Commons Attribution 4.0 International Public License (CC-BY 4.0), a copy of which is available at: (https://creativecommons.org/licenses/by/4.0/legalcode). This license permits unrestricted use, distribution, and reproduction in any medium, provided the original author and source are credited. 